\title{
Die subtiele aanleg en moontlikhede van die nominale styl: 'n Studie in Nuwe- Testamentiese Grieks
}

\author{
PB Boshoff
}

\begin{abstract}
The subtle nature and possibilities of the nominal style: A strdy is New Testament Greek

Nominalization as a figure of speech in the New Testament Greek or any other literature has not yet come to its full value. Nominalivation occurn when events in the deep structure are presented in the maf in nominal form. The nominal form is chosen for the sake of certuin foci. The method used to determine the specific contribution of the nominal form is to compare the nominal form with its verbal functions of style have ation, Spatialization, Degrading, Manifestation of cour
\end{abstract}

\section{INLEIDING}

Nominalisering is nog nie as stilistiese term gevestig nie en dit is 'n leemte. Mens kry in letterkundige termlyste of geen verwysing daarna nie, soos by Grové (1963) en Cuddon (1977), òf jy kan in alle tale lees dat nominalisering ' $n$ liefhebbery van die jongste eeu en van vandag is: in Engels (Turner 1975: 102-103); in Frans (Geyser 1981: 41); in Duits (Best 1982: 344). Die siening dat nominalisering so ' $n$ laatkommer is, kon dien as die verklaring vir die min kennis wat ons daarvan het. Maar ek betwyfel dit of ons die gebruik of nie-gebruik van nominalisering aan ' $n$ bepaalde periode kan koppel. Dat nominalisering 'n moderne neiging is, is een van daardie oortuigings wat navorsers by mekaar oorneem sonder om die waarheid daarvan te toets. 'n Ou skrywer soos Paulus het baie genominaliseer. En verder, as die neiging vandag sou

- Hierdie artikel is gebaseer op 'n MA-verhandeling (Boshoff 1986). Ek is aan prof Herman du Toit (1987) dank verskuldig vir die resensie en die kritiek daaroor. Hier word die saak dan verder gevoer. 
wees om te nominaliseer, hoe sal 'n mens die verskynsel verklaar dat nominale vorme in die Nuwe Testament in moderne vertalings dikwels verbaliserend vertaal word? As voorbeeld kan Markus 1: 4 dien, wat letterlik in Grieks lui: 'Johannes die Doper was in die woestyn en verkondigend die doop van bekering tot vergifnis van sondes'. Die Nuwe Afrikaanse Vertaling vertaal:

Só het Johannes die Doper in die woestyn opgetree. Hy het verkondig dat die mense hulle moet bekeer sodat God hulle sondes kan vergewe, en dat hulle hulle moet laat doop.

\section{Good News For Modern Man:}

So John appeared in the desert, baptizing people and preaching his message. 'Turn away from your sins and be baptized', he told the people, 'and God will forgive your sins'.

\section{Die Gute Nachricht}

Dies ging in Erfüllung, als der Täufer Johannes in der Wüste auftrat. Er sagte zu den Menschen: 'Ändert euch und lasst euch taufen, dann wird Gott euch eure Schuld vergeben!'

Op grond van moderne Bybelvertalings sou mens kon dink dat die neiging vandag eerder weg van die nominale vorme is met 'n groter liefde vir die verbale vorme. Moderne vertalings word immers verdedig met die argument dat daar 'ontwikkeling' (vgl Oberholzer 1984: 83) in die betrokke taal plaasgevind het. Niemand sal natuurlik wil ontken dat tale ontwikkel nie. Maar om taalontwikkeling gelyk te stel aan die beleid wat ' $n$ vertalerspan volg kan seker ook nie gedoen word nie. Nuwe vertalings is 'dinamies' omdat daarop gekonsentreer word om nie vorme te vertaal nie, maar betekenis. 'Die lang sinne moet opgebreek word in korter sinne en strewe na eenvoud. Maak soms eksplisiet wat implisiet in die teks is' (vgl Oberholzer 1984: 84). Mens kan verwag dat hierdie doelwitte verbale vorme ten koste van nominale vorme sal bevoordeel. Daarom sal dit ook verkeerd wees om te beweer dat die verbale styl tipies van hedendaagse taal is. Dit is nie die moderne taal wat 'n voorkeur vir verbale vorme het nie, maar die vertalers. Op grond van hulle liefde vir die werkwoord in plaas van die nominale vorm sou mens die hedendaagse Bybelvertalers as manne van die daad kan beskryf.

Geyser (1981: 36 ) bied 'n studie oor die gebruik van verbale aksie en 
sy nominale vorm in Frans en Afrikaans aan waarin sy die Afrikaanse vertalings met oorspronklike Franse tekste vergelyk. Sy het bevind dat daar ' $n$ hoër frekwensie van nominalisering in Frans as Afrikaans is. Dit kan aan twee oorsake toegeskryf word, eerstens dat verbalisering iets eie aan Afrikaans is en tweedens dat dit by elke vertaler ingebore is om verhelderend te vertaal (Geyser 1981: 36). Uiteindelik kom Geyser (1981: 130-136) tot die konklusie dat Afrikaans as taal 'n voorkeur het vir die verbale struktuur. Haar konklusie moet bevraagteken word omdat sy nie kon aantoon dat Afrikaans nie die gevraagde nominale vorme het nie. Sy noem dat ' $n$ groot persentasie van Afrikaanse ontnominaliserings van Franse nominale vorme op voorsetsels volg (Geyser 1981: 46). Byvoorbeeld ' $\mathrm{J}$ ' espérais pouvoir le garder prěs de moi jusqu' à l'arrivée du bateau' wat in die Afrikaanse vertaling 'Ek het gehoop ek kon hom by my hou tot die boot kom' geword het. Maar 'tot by die koms van die boot' is ook goeie Afrikaans. Dit gaan nie hier om die taalgevoel en konvensies van die ontvangertaal wat anders is as die van die oorspronklike taal nie. Die verskil tussen 'tot die boot kom' en 'tot by die koms van die boot' is nie dat die een vloeiender Afrikaans is as die ander nie. Die verskil kom daarby dat 'tot die boot kom' meer op 'die boot' fokus, terwyl 'tot by die koms van die boot' op 'koms' fokus. Afrikaans het dus wel die nominale vorme. Die voorkeur vir die verbale struktuur is die vertalers se voorkeur en nie Afrikaans s'n nie. Ek maak hierdie stelling omdat nominalisering sekere inherente moontlikhede het, wat nie van taal tot taal sal verskil nie, ook nie van tyd tot tyd nie.

In die moderne linguistiek kan onderskei word tussen oppervlakstruktuur en dieptestruktuur. Oppervlakstruktuur is die taal wat ons lees en hoor. Onder hierdie oppervlak lê die verhoudinge tussen die taalelemente verborge. Wanneer iemand die werklike bedoeling van 'n stuk taal wil begryp moet dit wat verborge is aan die lig kom: Die oppervlakstruktuur, naamlik 'die doop van bekering tot vergifnis van sondes' word gewoonlik verklaar as 'dat mense hulle moet bekeer en moet laat doop sodat God vergewe dat hulle gesondig het'. Die stuk word soms onbewus heel gemaklik deur die begryper ontleed en ander kere moet hy behoorlik sukkel en konsentreer om sin uit te maak. In ons voorbeeld was dit vir die vertalers makliker om te sê dat 'doop' beteken: 'Mense moet hulle laat doop' as om te sê dat 'doop van bekering' beteken: 'dat mense hulle moet bekeer en laat doop'.

Net na die ontdekking van hierdie twee vlakke het taalkundiges die twee vlakke teen mekaar afgespeel en gemeen dat die oppervlakstruktuur onbelangrik is omdat dit net die uiterlike vorm van die diepte- 
struktuur is, wat die enigste draer van die betekenis is (Louw 1976: 100). Hierdie siening was te eensydig en is vervang met die insig dat altwee vlakke help om die betekenis te bepaal. Die vorm waarin ' $n$ saak gestel word is gekies omdat dit die bepaalde betekenis die beste sal weergee. 'Die manier hoe dit gesê word is deel van die semantiese' (Louw 1976: 100).

Vir my lyk dit of hierdie waardevolle insig nie genoegsaam ingedring het by die interpretasie van nominale vorme nie. Die stief behandeling wat normalisering as stylfiguur ontvang kom van die oortuiging dat die variante van verbalisering en nominalisering hoofsaaklik ' $n$ verskil op leksikale vlak ten opsigte van die grammatikale vorm verteenwoordig, dit wil sê daar is twee vorme met dieselfde leksikale inhoud en die een of die ander word gebruik met die verskil dat byvoorbeeld 'die wil van God' dieselfde sê maar op 'n gewigtige, deftige, indrukwekkende Sondagstoon, as 'God wil', wat die gemaklik vloeiende weergawe is. Die mode van 'dinamiese' vertalings kan dan verklaar word as ' $n$ bewuste wegbeweeg van die deftige styl omdat die semantiese kommunikatiewe effek daarvan as baie laag waardeer word en daar gestreef word na 'n duideliker oordrag van betekenis.

Verdere ondersoek moet nou gedoen word en ons moet vra: Is die lastige deftigheid en verhewe vlak van kommunikasie 'n voldoende verklaring van die nominale vorme soos algemeen aanvaar word (vgl Ponelis 1979: 480; Geyser 1981: 64)? Is daar nie ander werklike stylfunksies wat nominalisering verrig nie? Wat 'die wil van God' betref sien ons dat die nominalisering van 'wil' dit in die beklemtoonde posisie plaas terwyl die semantiese onderwerp 'God' kommunikatief afgegradeer word. Die begeerte 'wil' word geaksentueer, terwyl 'God wil' stel dat God wil, met die aksent waarskynlik op 'God'.

Wanneer 'n ervaring onder weloorwoë woorde gebring is, het die ervaring nie meer 'n onafhanklike bestaan los van die vorm waarin dit uitgedruk is nie. Mens kan die uitspraak nie sonder die vorm waarin dit gestel is verstaan nie. Die vorm is nie slegs draer van die inhoud nie, maar maak voortaan deel uit van die inhoud. Die inhoud is afhanklik van die vorm en in hierdie geval van die nominale vorm. Die nominale vorm hou die belofte in dat hy die blote semantiese waarde van die woord verder kan voer as die verbale vorm om op sinsvlak en ook op diskoersvlak ' $n$ bepaalde betekenis oor te dra. Dit wil sê die leser moet verwag dat die nominale vorme meer wil wees as bloot ' $n$ ander vorm met dieselfde betekenis as die korresponderende werkwoorde. In 1 Petrus 3: 15 staan byvoorbeeld 'wees altyd gereed om ' $n$ antwoord te 
gee aan elkeen wat van julle 'n verduideliking eis oor die hoop in julle'. Die agtergrond waarteen hierdie opdrag gegee word is sekerlik nie dat die lesers van die brief geweier het om te antwoord as hulle om ' $n$ verduideliking gevra is nie. Die bedoeling van die opdrag is eerder 'leef so dat julle in die situasie kom waar julle rekenskap gee van die hoop in julle'. Dit wil sê 'sorg dat julle hoop' of nog meer op die man af: 'hoop!' Deur hoop te nominaliseer en met die voorsetsel 'aangaande' as die inhoud van die vraag aan te dui en oënskynlik 'n ander mindere opdrag te gee, naamlik 'wees altyd gereed', slaag die skrywer daarin om sagter oor te kom. Sy doel is om te oorreed en nie om te oorrompel nie. Die nominale vorm 'hoop' is as deel van die hele segging gekies ter wille van die boodskap. Dit is fyn styl.

Nominalisering vind plaas wanneer gebeure in die dieptestruktuur in die oppervlakstruktuur in nominale vorm aangebied word. As jy sê dat die nominale vorm deftiger as die verbale vorm is, veronderstel jy dat altwee in wese dieselfde sê, soos wat die moderne Bybelvertalings te kenne gee, dat die verbale vorm die dinamiese ekwivalent van die nominale vorm is. Maar hierdie vertrekpunt is nie korrek nie. Deftigheid laat mens aan die uiterlike dink, dis 'n oordeel oor die uiterlike. Geyser (1981: 132) gee ' $n$ tree in die regte rigting as sy nominalisering met die meer belowende term intellectualisation du verbe beskryf. Ek sal nominalisering liewer 'n subtilisering van die aksie noem, want die nominale vorm is subtiele uitdrukking en aanwending van die aksie. Die term subtiliteit laat reg geskied aan die rykheid van betekenismoontlikhede van nominale vorme.

In Grieks kan selfstandige naamwoorde, infinitiewe, adjektiewe en deelwoorde gebruik word vir nominalisering (Louw 1979: 21-22). Uit hierdie vier moontlikhede het ek hoofsaaklik die optrede van die selfstandige naamwoord gevolg.

Die metode wat gebruik is, is om telkens die eie aanleg en moontlikhede van die nominale vorm vas te stel in vergelyking met die verbale variant wat moet geld as die 'normale' wyse waarop aksie uitgedruk word. Dit doen ek sonder om te vra of die spesifieke taalgebruiker inderdaad ' $n$ werkwoord geken het om in die plek van die nominale vorm wat hy wel gebruik het, te stel. Taal het die potensiaal om nominale vorme én verbale vorme te verskaf en hierdie potensiaal kan benut word.

Vyf stylfunksies van nominalisering het na vore gekom: Aksentuering; Verruimteliking; Degradering; Hoflikheidsbetuiging; Profilering. Hierdie koderingsmoontlikhede van nominalisering moet in ag geneem 
word by die dekodering daarvan. Die erkenning van die styleffekte van nominalisering maak 'n noodsaaklike deel uit van die eksegeet se werk as hy nie sleg wil lees nie. Vir vertaling kan daar ook belangrike oorweginge gestel word: Aan die een kant word beweer dat die nominale styl swaar en formeel is wat maak dat mens moeiliker daaraan lees, maar aan die ander kant kon ek aantoon dat dit verlies aan betekenis meebring wanneer nominalisering sonder meer omgestel word en verbaliserend vertaal is. Die sogenaamde dinamiese vertaling verloor dan in hierdie opsig deel van die oorspronklike seggingskrag.

Hoewel die studieveld tot die Nuwe Testamentiese Grieks beperk was, is die resultate wat bereik is ook op ander tale van toepassing. Die aanwending van nominalisering in Grieks verskil nie van die aanwending daarvan in die vertalings van die Nuwe Testament wat ek vergelyk het nie. Ek wil die voorspelling waag dat die stylfunksies van nominalisering nie net geld vir Nuwe Testamentiese Grieks nie, maar oor die algemeen vir nominale vorme in alle tale.

In wat volg word elke stylfunksie bespreek aan die hand van voorbeelde. Die Griekse teks word deur 'n Afrikaanse vertaling verteenwoordig, waarin ek veral by die nominale vorme gehou het, en die nominale vorm onder bespreking is onderstreep.

\section{AKSENTUERING}

Nominalisering van gebeure is ' $n$ manier waarop inligting uit 'n neutrale posisie gelig kan word om benadruk te word. 'n Mooi voorbeeld van nominalisering as beklemtoningsmiddel staan in 1 Petrus 3: 7:

Mans, hoewel julle met julle vrouens saamleef in die wete dat hulle die swakker geslag is, bewys nogtans eer aan hulle, want hulle is ook mede-erfgename van die gawe van die lewe, sodat nie verhinder word nie - julle gebede.

Aanvanklik is die aandag op 'mans' gevestig. Hulle is die aangesprokenes. 'n Geverbaliseerde einde soos by die Nuwe Afrikaanse Vertaling 'Dan sal julle kan bid sonder dat iets julle hinder' behou die aandag enduit op 'julle', dit wil sê 'mans'. 'Julle' moet die aksie van bid uitvoer. Die oorspronklike teks 'sodat nie verhinder word nie - julle gebede' vervang egter 'mans' met 'gebede' in die nadruksposisie. 'Mans' en 
'gebede' staan ook in kontras in die nadruksposisies aan die begin en einde van die sin.

In Filippense 4: 5 lees ons: 'Die Here is naby'. En 'n verwante uitspraak in 2 Tessalonisense 1: 7 lui 'by die verskyning van die Here Jesus'. In albei uitsprake gaan dit oor die Here en sy koms, maar die klem word verskillend gelê. 'Die Here is naby' verseker die lesers dat die Een in wie hulle tot nou toe vertrou het naby is. Daar is kontinuiteit tussen nou en wat gaan kom. Die voorafgaande sê dan ook 'wees altyd bly in die Here'. Die uiting 'by die verskyning van die Here Jesus' is deel van 'n oproep tot standvastigheid in verdrukkende omstandighede: Aan hulle, die verdruktes, en aan ons sal Hy verligting gee by die verskyning van die Here Jesus met sy magtige engele uit die hemel. In hierdie geval is daar nie kontinuiteit tussen nou en wat gaan kom nie. Die 'verskyning' gaan verligting bring van die verdrukking. Die vraag na die tyd wanneer die gelowiges verligting sal ontvang word beantwoord met 'by die verskyning van die Here Jesus'. Hier wou die skrywer meer op die 'koms' as op die 'Here' fokus. Die manier waarop hy dit kon regkry is om 'verskyn' in 'wanneer die Here Jesus verskyn' te nominaliseer, naamlik 'by die verskyning van die Here Jesus'. Dit is natuurlik moontlik om 'wanneer die Here Jesus verskyn' so uit te spreek dat die klem op 'verskyn' val. Maar suiwer op geskrewe gesigswaarde geneem aksentueer 'by die verskyning van die Here Jesus' die 'verskyning'. In vergelyking hiermee fokus 'wanneer die Here Jesus verskyn' eerder op 'die Here Jesus'.

\section{VERRUIMTELIKING}

Brink (1987: 107) wys daarop dat ruimte ' $n$ verwaarloosde onderwerp in die literatuurstudie is. Wybenga (1983: 146) het dit gewaag om te stel dat nominalisering nie bloot gebeure weergee nie, maar 'n saak, dit wil sê die gebeure word saaklik voorgestel sodat dit eerder ruimtelike as tydskenmerke het. Du Toit (1987: 792) vra na die oorgang van saak na ruimte. Dat nominalisering ' $n$ saak weergee is aanvaarbaar, maar hoe kan die nominale vorm ruimtelike kenmerke hê? Watter ruimtelike konnotasie kan 'in' hê in Filippense 1: 9 'Ek bid dat julle liefde al hoe meer sal toeneem in begrip en in alle insig'? Ons moet natuurlik onthou dat dit hier gaan om in-taal-uitgebeelde ruimte. Die voorsetsel 'in' dui tog op ruimte. Vir die wat my nie wil glo nie herinner Brink (1987: 107) daaraan dat mens by 'elke voorsetsel wat verhoudinge aandui - in, op, 
oor, deur, agter, voor ...' ook ruimte moet aflei. Om 'n ander naam te gee aan die ruimte van 'begrip en alle insig' sou jy kon sê die ruimte van goeie gesindheid.

Verruimteliking hou verband met beskrywing, want beskrywing kan ruimtelik georganiseer word (Nida 1981: 29). 'n Saak of voorwerp word teen ' $n$ agtergrond of met betrekking tot ander sake geteken. Die 'tot gebed' in 'Die einde van alles is naby. Daarom moet julle selfbeheers en nugter wees tot gebed' (1 Petrus 4: 7) is eerder beskrywend, terwyl die verbale vorm 'sodat julle kan bid' (NAV) onder verslag ingedeel moet word want hier word die gebeure-aspek uitgelig en van die handeling verslag gedoen. Nominalisering beskryf terwyl verbalisering verslag doen. Die ruimte wat deur 'gebed' opgeroep word kan beskryf word as die ruimte waar die gemeente met sy behoeftes en nood aan God onderwerp word. Die geverbaliseerde vertaling laat mens dink aan die bid van ' $n$ gebed wat met 'Onse Vader' kan begin en met 'amen' eindig. Die vertaling dwing die gemeente op die knieë waar die teks die gemeente binne die ruimte van oorgawe aan God wou laat leef.

'n Opwindende voorbeeld waar ruimte getaal word staan in Markus 1: 4: 'Johanns die Doper was in die woestyn en verkondigend die doop van bekering tot vergifnis van sondes'. Moet woestyn hier as fisieke ruimte verstaan word of moet ons 'n meerdere waarde daaraan toeken? Anders gestel: is 'doop van bekering tot vergifnis van sondes in die woestyn' gelyk aan 'julle hier in die woestyn - bekeer julle! Laat julle doop! Sodat God julle sondes kan vergewe'?

Ons het dit al uitgemaak dat nominale vorme beskryf en beskrywing maak gebruik van ruimtelike plasing. Johannes het al verkondigende die sake van 'doop van bekering tot vergifnis van sondes' in die woestyn staangemaak. Hierdie sake is deel van die ruimte van 'woestyn' gemaak. 'Woestyn' kan nie meer sonder hulle gedink word nie. Aan die ruimte van 'woestyn' word dus ' $n$ teologiese konnotasie gegee. 'Woestyn' is die ruimte van 'doop van bekering tot vergifnis van sondes'. En andersom kan 'doop van bekering tot vergifnis van sondes' nie meer los van 'woestyn' gemaak word nie. 'Doop van bekering tot vergifnis van sondes' is die ruimte van 'woestyn', wat weer sy eie konnotasie bydra tot die begrippe van 'doop van bekering tot vergifnis van sondes'. 'Woestyn' kan ons beskryf as die ruimte waar die mens homself nie teen God kan handhaaf nie (vgl Schmithals 1979: 79). Dit gaan om die karakter en gees van die woestyn waarna 'doop van bekering tot vergifnis van sondes' verwys en nie om die feite van bekering, doop en vergifnis van sondes nie. 
Die verbale vorme gee verslag van wat gebeur in temporele volgorde. Ons lees dan: 'Johannes was in die woestyn en het verkondig: "Bekeer julle! Laat julle doop sodat julle sondes vergewe kan word." ' Hiervolgens is die mense wat - in die woestyn - na hom luister nog nie bekeer nie. Hulle hoor eers daar: bekeer julle! Maar dit is onsin, want om in die woestyn te wees beteken om bekeer te wees. Woestyn en bekering is in een ruimte.

Die verbaliserende vertaling van die Nuwe Afrikaanse Vertaling:

3 Iemand roep in die woestyn:

Maak die pad vir die Here gereed, maak die paaie vir Hom reguit.

4 Só het Johannes die Doper in die woestyn opgetree.

Hy het verkondig dat die mense hulle moet bekeer

sodat God hulle sondes kan vergewe, en dat hulle

hulle moet laat doop.

moet dus as eksegeties onverantwoord beskou word. In plaas van 'n vertaling van die teks is dit eerder ' $n$ poging om by die storie agter die teks uit te kom. Hiermee bedoel ek dat dit in die vertaling gaan om die historiese feite van bekering, doop en vergifnis van sondes, terwyl die woestyn 'n spesifieke plek word en sy beeldkarakter inboet.

Die oorsprong van hierdie vertaalsonde lê seker in Bratcher en Nida se $A$ translator's handbook on the Gospel of Mark waar die woestyn aangedui word as die woeste landstreek wes van die Dooie See (1961: 11). Bratcher en Nida sê verder dat Markus 1: 4 'probably the most difficult verse in the entire Gospel of Mark' is (1961: 12). Die vers se moeilikheid is te wyte aan die ingewikkelde sintaksis, sê hulle. Na aanleiding van die misplaaste verbaliserende vertalings, wat op hierdie handboek gebaseer is, sal mens moet sê dat die vers dalk nog moeiliker is as wat hierdie vertaalraadgewers vermoed het.

Dit kan ' $n$ interessante studie wees om na te gaan in hoe 'n mate byvoorbeeld die Nuwe Afrikaanse Vertaling historiserend vertaal. Die historiserende vertalings maak die Bybel self deel van die historiese kritiek. Die vertaling word 'n poging om agter die gegewe wêreld in te dring. Hierdie pretensie en werkswyse het ook teologiese implikasies, want dit is anders as die opvatting dat ons die waarheid van die Skrif nie anders nie as deur die Skrif self, die waarheid van Christus nie anders nie as deur die woord wat van Hom getuig, kan ken. 


\section{DEGRADERING}

Alles in ' $n$ taalaanbod kan nie as ewe belangrik bedoel wees of beskou word nie. ' $n$ Spreker kan die behoefte hê om die aandag van 'n bepaalde uiting af weg te lei. Dit moet minder prominent wees en 'n lae diskoerswaarde hê. Dit beteken egter nie dat so'n uiting 'sommer maar net' genoem word nie (vgl Ponelis 1979: 544). Deur een element te onderdruk word 'n ander weer geaktiveer (vgl Wybenga 1987: 72).

Nominalisering word gebruik om inligting wat in verbale vorm op die voorgrond sou wees in die agtergrond te dwing en sodoende te degradeer. In nominale vorm word die inligting as ' $t$ ware gedwing om ondergronds te gaan. Paulus doen sy gebed 'met blydskap' (Fil 1: 4b). Deur te nominaliseer en die nominale vorm deel van die voorsetselstuk 'met blydskap' te maak word die hoër sin 'ek verheug my' sintakties degradeer tot 'n bysin van wyse. 'Met blydskap' gee die manier aan waarop Paulus sy gebed doen, naamlik 'ek doen die gebed met blydskap'.

In 1 Petrus 4: 9 staan 'Wees gasvry teenoor mekaar sonder klagte'. Hier druk die naamwoordelike vorm 'klagte' die toestand uit waarbinne die aksie 'wees gasvry' plaasvind, naamlik 'wees gasvry sonder klagte'. 'Sonder klagte' karakteriseer die wyse waarop 'wees gasvry' uitgevoer moet word, dit wil sê 'sonder klagte'. 'Sonder klagte' is 'n subordinerende kwalifikasie van die hoofgebeure 'wees gasvry'. Indien klagte geverbaliseer word, verloor hy sy toestandkarakter en word 'n spesifieke aksie 'sonder dat julle kla'. Die twee aksies 'wees gasvry' en 'sonder dat julle kla' vind gelyktydig plaas. Op die spits gedryf is 'wees gasvry sonder dat julle kla' dieselfde as 'terwyl julle gasvry is, kla julle nie'. In hierdie sin verskaf 'wees gasvry' die tydsduur waarbinne die hoofgebeure 'sonder dat julle kla' afspeel. Deur 'klagte' te nominaliseer fokus die betoog op 'wees gasvry' en word 'sonder klagte' op die agtergrond gehou, sodoende word die positiewe 'wees gasvry' uitgelig. In Filippense 1: 20 sê Paulus:

volgens my verlange en hoop: in niks sal ek my hoef te skaam nie, maar dat Christus met alle vrymoedigheid, soos altyd ook nou, deur myself verheerlik word, of dit deur die lewe is of deur die dood.

'Volgens my verlange en hoop' is 'n verhoudingskonstruksie wat die maat aangee waarvolgens die apostel hom nie sal hoef te skaam nie. Om dit duidelik te stel kan mens die sin soos volg weergee: 'volgens my 
verlange en hoop sal ek my in niks hoef te skaam nie'. Die 'verlange' en 'hoop' vorm die agtergrond waarteen die hoofgebeure naamlik 'in niks hoef ek my te skaam nie' plaasvind.

Die Nuwe Afrikaanse Vertaling het hierdie degraderende funksie van die nominale vorme nie raakgesien nie en vertaal:

Dit is my vurige verlange, en daarna sien ek uit, dat ek niks sal doen waarvoor ek my sal hoef te skaam nie.

Die dit-splitsingkonstruksie 'dit is my vurige verlange' plaas 'verlange' op die voorgrond en die verbale weergawe 'daarna sien ek uit' haal hoop uit die agtergrondsposisie uit om 'in niks hoef ek my te skaam nie' uit die voorgrond te druk. Hier was die dinamiese vertaling darem te vurig.

\section{HOFLIKHEIDSBETUIGING}

Ponelis (1979: 487) stel dat nominaalkonstruksies naamwoordstukke is wat nie onderskei tussen die sinstipes nie. Of die sin 'n stelling, 'n vraag of ' $n$ bevel is kom by die naamwoordstukke nie uit nie. Die naamwoordelike vorm kan korrespondeer met ' $n$ bevelsin maar is self onbevoeg om die sinskenmerk van bevel uit te druk. Die nominale vorm 'liefde' korrespondeer met die bevelsvorm 'hê lief!' maar gee nie weer dat dit ' $n$ bevelsin moet wees nie.

Dit is seker waar dat nominaalkonstruksies op grammatikale vlak nie aan sinstipes uitdrukking kan gee nie. 'n Gedeelte soos 1 Korintiërs 13: 4

Die liefde is geduldig,

die liefde is vriendelik,

dit is nie afgunstig nie.

Die liefde praat nie groot nie,

is nie verwaand nie.

moet dan as ' $n$ stelling verstaan word wat inligting gee oor wat die liefde doen en nie doen nie. Maar hierdie grammatiese interpretasie bied nie 'n bevredigende verklaring nie, want daar is nog iets op die spel wat op die sinsvlak en diskoersvlak na vore kom en wat ons die uitingseffek kan noem. Die effek van hierdie uiting is nie dat objek- 
tiewe kennis meegedeel word nie. Paulus wil die lesers geduldig, vriendelik, ensovoorts kry. En hy weet dat dit net moontlik is as hulle liefhet. In plaas daarvan om reguit te sê: hê lief!, nominaliseer hy die aksie in 'die liefde'. Paulus veronderstel dat elkeen wat dit lees homself met 'die liefde' sal wil vereenselwig. En as dit gebeur, het elkeen self gekies om lief te hê, wat ook die bedoeling is.

Deur van die nominale vorm gebruik te maak kommunikeer Paulus op indirekte wyse en neem die menslike faktor in ag dat mense nie graag onder dwang wil wees nie. Die funksie van die nominale vorm in hierdie geval is om hoflikheid te betuig. Die verbale 'hê lief!' word deur die nominale vorm 'die liefde' hoflik gemaak. Hoflikheid behels dat die ander gespreksgenoot in ag geneem word deurdat aan hom 'n keuse gelaat word, dat daar ' $n$ afstand tussen spreker en aangesprokene eerbiedig sal word, dit wil sê dat die spreker hom nie opdring nie, en deurdat die spreker vriendelik sal bly (vgl Van Rensburg 1982: 323).

Hierdie hoflikheid moet nie so verstaan word dat die Christelike waarheid maar net die natuurlike aanleg, gawes en kragte van die mens na vore bring nie. Dit sou dan neerkom op 'n tevredenheid met die goeie hoedanighede van die menslike natuur, waarby geloof in die Christelike sin uitgesluit word. Hoflikheid as deel van die verkondiging van die kerk, gee uitdrukking aan die feit dat die goddelike waarheid ook die menslike waarheid is. Die belydenis van die goddelike waarheid wek lewe in mense want dit voldoen aan menslike behoeftes. Die beleefde toon gee erkenning en uitdrukking hieraan.

Nog ' $n$ voorbeeld van hoe beleefd die nominale vorm kan wees lees ons in Filippense 2: 1-2:

1 As daar dan enige vermaning in Christus is, as daar enige aanmoediging van liefde is, as daar enige gemeenskap van die Gees is, as daar enige innige meegevoel en meelewing is:

2 maak dan nou my blydskap volkome...

Die skrywer maak hier gebruik van 'n reeks voorwaardesinne. Met hierdie sintaktiese konstruksie word reeds afstand tussen die aangesprokenes en wat moet gebeur gesuggereer. 'n Verdere tegniek wat die skrywer gebruik om sag oor te kom is om die aksies te nominaliseer en as onpersoonlike omskrywings aan te bied, naamlik 'as daar enige ...'. Die betoog wil naamlik sê: 
laat julle in Christus vermaan word, laat julle in liefde aangemoedig word, beoefen gemeenskap met die Gees, hê meegevoel en meelewing ...

Deur sy woorde op die manier in te span vereenselwig Paulus hom met die aangesprokenes, sê hy nie dadelik wat hy wil sê nie, lei hy die aangesprokenes om self die keuse te maak. As dit alles gedaan is voel hy hom gereed om opsommend te versoek: 'maak dan nou my blydskap volkome ...'.

Die versigtigheid en beskeidenheid van die woordvoerder blyk ook duidelik in 1 Johannes 1: 3 :

Hom wat ons gesien het en gehoor het, verkondig ons ook aan julle, sodat julle gemeenskap met ons sal hê. En ons gemeenskap is met die Vader en met sy Seun, Jesus Christus.

Die sin 'sodat julle gemeenskap sal hê' kry sy bepaalde kleur uit die verhouding tussen die skrywer en sy lesers. Die skrywer wil naamlik die gedrag van die lesers verander. Uit diplomatiese oorwegings kom hy nie met ' $n$ imperatief nie, maar met ' $n$ doelsin ter verduideliking van sy eie aktiwiteit van verkondiging. Die aksie word in 'gemeenskap' genominaliseer, want die werkwoordelike vorm sou selfs in 'n doelsin te blatant op die lesers aanspraak maak: 'sodat julle gemeenskap sal beoefen', met inchoatiewe betekenis 'begin beoefen' in ' $n$ doelsin. Die naamwoordelike vorm degradeer die aksie tot voorwerp en met behulp van die werkwoord 'hê' as reeds verkreë voorgestel: 'sodat julle gemeenskap sal hê'. 'n Hoogs beleefde manier van sê. So vervul nominalisering die retoriese funksie van hoflikheid.

\section{PROFILERING}

Louw (1975: 100-101) stel dat werkwoorde ook in Grieks nie duidelik gemerk is wat aspek betref nie: 'Hy sondig' druk nie duidelik uit dat die handeling voortduur nie. Dit kan bedoel wees as die stel van 'n feit, die feit word bloot genoem sonder dat enige uitspraak oor die aard van die gebeure gemaak word. Oor die begin, die duur of die einde van die aksie word niks gesê nie. Byvoorbeeld: 'Dit skrywe ek aan julle, my liewe kinders, dat julle nie moet sondig nie'. Hier word die aktualiteit van sonde gekonstateer sonder dat die aard van die gebeure beskryf 
word. In die uitdrukking 'hy lewe in sonde' word die handeling duidelik gemerk wat die aspek van duratiwiteit betref. In Grieks sou dit uitgedruk kan word met 'hy doen sonde'. Die metode wat gebruik word om die gebeure 'sonde' se verloop duidelik te merk is om die aksie in nominale vorm te plaas: 'sonde' en die onvoltooide aspek van die gebeure te verbaliseer: 'lewe' en 'doen'.

Die metode om die gebeure te nominaliseer en die verloop van die gebeure met ' $n$ verbale vorm aan te dui is inderdaad ' $n$ beproefde manier om van die profiel van die handeling verslag te doen. Profilering beskryf die wyse van aspekaanduiding met nominalisering van die gebeure en verbalisering van die aspek daarvan.

'n Mooi voorbeeld van Nuwe Testamentiese profilering staan in Johannes 2: 5a: 'Wie sy woord egter gehoorsaam - in hom het die liefde van God waarlik afgerond geraak.' Die nominalisering van 'liefde' stel die skrywer in staat om met die abstrak van aspek 'afrond' in die werkwoordsposisie op voltooidheid in die handelingsprofiel te fokus. Die handeling is voltooi en het die toestand van voltooidheid bereik.

In 1 Petrus 4: 17a: 'Want dis tyd van die begin van die oordeel vanaf die huis van God' word die aspektiese waarde van die aksie 'oordeel' deur die infinitief 'begin' gemerk. Hier sal mens moet uitmaak of die 'oordeel' op die punt staan om te begin, soos Arichea en Nida (1980: 151) dit verstaan, en of dit reeds begin het, soos die Nuwe Afrikaanse Vertaling dit vertolk: 'Die tyd vir die oordeel het aangebreek; dit begin by die huis van God'. Normaalweg beteken 'begin' tog nie 'op die punt staan om te begin' nie. Die spreker bevind hom nie op 'n punt voor die gebeure nie, maar by die aanvangspunt, dit wil sê die 'oordeel het reeds begin'. Die verloop van die gebeure 'oordeel' in nominale vorm word nie net deur die verbalisering van die aspek 'begin' uitgelig nie, maar nog verder verskerp deur 'tyd' in die onderwerpsposisie: 'dis tyd van die begin van die oordeel ...'

Die aspek van progressie word in Kolossense 1: 23a gemerk:

Maar dan moet julle volhard in die geloof, gegrond en vas, en julle nie laat losruk van die hoop van die evangelie wat julle gehoor het nie.

Die abstrak van aspek 'volhou' dui op duratiwiteit in die handelingsprofiel en van die naamwoordelike vorm 'geloof'. Die aspek van voortgang word nog verder onderstreep deur die frase 'gegrond en vas' en wat daarop volg. 


\section{SLOTOPMERKING}

Soos wat die ou Bybelvertalings elkeen 'n eie vertalingstegniek laat sien, volg die moderne Bybelvertalings ook bepaalde tendense. Dit is sekerlik ook ons taak om verantwoording te doen van die metodes wat nou gevolg word en indien die metode die vrug van ' $n$ bepaalde geesteshouding is, moet ons daaroor ook nadink. Hierdie opstel is 'n poging in hierdie rigting.

Een van die bekende reëls waarmee Bybelwetenskaplikes vertroud is, lectio difficilior, lui dat die tekslesing wat grammatikaal en saaklik moeiliker is, voorkeur moet geniet bo die makliker lesing, want afskrywers van tekste sal eerder 'n oorspronklik moeiliker lesing wil vergemaklik as om iets makliks te bemoeilik. Die vertalingstegniek om die subtiliteit van die nominale vorme prys te gee in die verbale weergawe lyk vir my na 'n voorkeur vir die makliker lesing. 'Moeilik' en 'maklik' is egter neutrale terme. In werklikheid gaan dit om reg en verkeerd. 'n Teks kan maar net een regte verklaring hê.

Ons moet vir die verdere argumente ook in aanmerking neem dat 'reg' en 'verkeerd' nie gelyk is aan 'stigtelik' en 'onstigtelik' nie. Ook 'n verkeerde verklaring van 'n Bybelteks kan stigtelik wees. Maar die kerk sal natuurlik sy bouwerk met die regte materiaal wil doen.

\section{Literatuurverwysings}

ALAND, K, Black, M, MARTINI, CM, METZGER, BM \& WIKGREN, A 1981. Novum Testamentum Graece. 26. Aufl. Post Eberhard Nestle et Erwin Nestle communiter ediderunt. Stuttgart: Deutsche Bibelstiftung.

ARICHEA, DC \& NIDA, EA 1980. A Translator's handbook on the first letter from Peter. New York: UBS. (Helps for Translators.)

BEST, OF 1982. Handbuch Literarischer Fachbegriffe: Definitionen und Beispiele. 8. Auflage und Neuausgabe. Frankfurt a M: Fischer.

BOSHOFF, PB 1986. Die interpretasie van nominalisering as styleffek in Nuwe Testamentiese Grieks. Ongepubliseerde MA-verhandeling, Universiteit van Pretoria.

BRATCHER, RG \& NIDA, EA 1961. A Translator's handbook on the Gospel of Mark. Leiden: Brill. (Helps for Translators.)

BRINK, AP 1987. Vertelkunde: 'n Inleiding tot die lees van verhalende tekste. Pretoria: Academica.

CUDDON, JA 1979. A dictionary of literary terms. London: Deutsch.

Die Bybel: Nuwe Vertaling 1984. 4de Druk. Kaapstad: Bybelgenootskap van Suid-Afrika.

Die Gute Nachricht: Das Neue Testament in heutigem Deutsch 1971. 3 Aufl. Stuttgart: Bibelanstalt.

DU TOIT, HC 1987. Oorsigartikel: Boshoff PB 1986, Die interpretasie van nominalisering as styleffek in Nuwe Testamentiese Grieks. Ongepubliseerde MA-verhandeling, Universiteit van Pretoria. HTS 43 789-795.

GEYSER, D 1981. Stylistique comparée du francais et de l'afrikaans: L'action verbale et sa 
forme nominalisée. Ongepubliseerde MA-verhandeling, Universiteit van Suid-Afrika, Pretoria.

Good News for modern man: The New Tetament in today's English version 1971. Cape Town: The Bible Society of South Africa.

GROVE, AP 1963. Letterkundige sakwoordeboek vir Afrikaans. 2de Uitg. Kaapstad: Nasou.

LOUW, JP 1975. Verbal aspect in the first letter of John. Neotestamentica 9, 98-104.

LOUW, JP 1976. Semantiek van Nuwe Testamentiese Grieks. Pretoria: Beta.

LOUW, JP 1979. Nominalisering van gebeure as stylkenmerk in Antieke Grieks. Taalfasette 26/2, 21-27.

NIDA, EA 1981. Signs, sense, translation. Pretoria: Universiteit van Pretoria.

OBERHOLZER, JP 1984. Die Afrikaanse Bybelvertaling 1983: Enkele aantekeninge. HTS 40/1, 82-91.

PONELIS, FA 1979. Afrikaanse sintaksis. Pretoria: Van Schaik.

SCHMITHALS, W 1979. Das Evangelium nach Markus. Gütersloh: Mohn. (ÖTK 2/1; GTB-Siebenstern 502, 503.)

TURNER, GW 1975. Stylistics. Harmondsworth: Penguin.

VAN RENSBURG, MCJ 1982. Hoflikheidsuitings: Maskers teen die erns, in Van Jaarsveld, GJ (red), Wat sê jy? Studies oor taalhandelinge in Afrikaans, 321-337. Johannesburg: McGraw-Hill.

WYBENGA, DM 1983. Grammatiese tydvergestalting in Afrikaans: 'n Linguistiese ondersoek aan die hand van enkele Afrikaanse kortverhale. Ongepubliseerde D Littproefskrif, Potchefstroomse Universiteit vir Christelike Hoër Onderwys.

WYBENGA, DM 1987. Diskoersanalise en stilistiek: 'n Inleiding. Pretoria: Serva. 